\title{
REFLECTIONS ON THE FREE FARE MOVEMENT AND OTHER "NEW SOCIAL MOVEMENTS"1
}

\author{
Pablo Ortellado ${ }^{2}$
}

\begin{abstract}
On June 6, 2013, the Free Fare Movement (Movimento Passe Livre) began a very aggressive campaign against the rise in bus and metro fares in São Paulo, Brazil. In an ultimately twoweek campaign, the movement organized six demonstrations blocking some of São Paulo's most vital avenues. After the demonstrations became massive (some in excess of one million people), both city and state governments relented and reduced the fares. The June mobilizations were horizontal, non-partisan, and based on direct action. These events are akin to other recent mobilizations such as Occupy Wall Street and the 15M movement in Spain but are different in one important aspect: they had only one demand-a 20-cent reduction in bus and metro fares. This one demand allowed the movement to develop a clear and successful strategy while retaining the horizontality and countercultural creativity of other new movements. Indeed, this series of demonstrations may have provided a model for coordinating a concern for processes with strategically aiming for outcomes.
\end{abstract}

Keywords: Free Fare Movement, Social movements, Counterculture, Demonstrations in Brazil.

\footnotetext{
${ }^{1}$ This is a slightly modified version of a text originally published as a postscript in: Vinte centavos: a luta contra o aumento. São Paulo: Veneta, 2013. The Editorial Board of Mediações thanks the author and publishers for having authorized this publication.

${ }^{2}$ Social activist and professor at the School of Arts, Sciences, and Humanities of the University of São Paulo (Universidade de São Paulo - USP), Brazil. paort@usp.br.
} 


\title{
REFLEXÕES SOBRE O MOVIMENTO PASSE LIVRE E OUTROS "NOVOS MOVIMENTOS SOCIAIS"
}

\begin{abstract}
RESUMO
Em 6 de junho de 2013, o Movimento Passe Livre iniciou um protesto muito agressivo contra 0 aumento das tarifas de ônibus e metrô em São Paulo, Brasil. Em uma jornada de duas semanas, o movimento organizou seis protestos que bloquearam algumas das avenidas mais importantes de São Paulo. Após os protestos ganharem um caráter massivo (alguns excederam um milhão de pessoas), tanto a prefeitura quanto o governo do estado cederam e reduziram as tarifas. As mobilizações de junho foram horizontais, apartidárias e baseadas na ação direta. Esses eventos guardam semelhança com outras mobilizações recentes, como o Ocupe Wall Street e o Movimento 15M na Espanha, mas são diferentes em um importante aspecto: eles tinham apenas uma demanda - a redução de 20 centavos nas tarifas de ônibus e metrô. Essa demanda única permitiu ao movimento desenvolver uma estratégia clara e bem-sucedida, ao passo que conservaram a horizontalidade e a criatividade contracultural de outros novos movimentos. Na verdade, essa série de protestos pode ter propiciado um modelo para a coordenação de um interesse em processos que apontam estrategicamente para resultados específicos.
\end{abstract}

Palavras-chave: Movimento Passe Livre. Movimentos sociais. Contracultura. Protestos no Brasil.

Vergnügungs-Reisende. - Sie steigen wie Tiere den Berg binauf, dumm und schwitzend; man batte ibnen zu sagen vergessen, daß es unterwegs schöne Aussichten gebe.

[Tourists. - They climb mountains like animals, stupid and sweating; one has forgotten to tell them that there are beautiful views on the way up.]

F. Nietzsche. Der Wanderer und sein Schatten, 202.

\section{OVERVALUING PROCESSES IN NEW SOCIAL MOVEMENTS}

$\mathrm{F}$ or many years, new social movements existed under a tension between process and outcome. The example of the protests in June 2013, in Brazil, leaves two opposite legacies: an extremely procedural dispersion and the fertile combination of process and outcome in the struggle against the rise in bus and metro fares. 
In recent decades, we have witnessed the birth of movements that are both horizontal, in terms of organization, and autonomous, in relation to political parties and institutions. These movements are usually focused on processes rather than outcomes. It is the means by which they act, horizontality, direct democracy, as well as the creativity of their actions that give them flavor and meaning. The struggles are vivid experiences of democratic communities and provide a place for counter-cultural selfexpression. This procedural dimension is sometimes overvalued and even opposed to the practical outcomes of political action.

More than 40 years ago, Mario Tronti (2006) proposed the inversion of Lenin's axiom, which states that social movements act in the short-term and that political parties act in the long-term. According to Lenin, workers left to their own would loose themselves in innocuous union struggles for salary increases because any gain in salary resulting from a successful struggle would be gradually reversed by increases in the cost of living. Therefore, the existence of a political party was essential to subject this shortterm struggle to a long-term transformation program. Tronti reverses this axiom by stating that the movement makes the long-term change by modifying the structure of social relations and that the political party (in the parliamentary sense) would be useful only to achieve specific goals.

Sometime later, Carl Boggs (1977) understood that the new movements were rooted in a prefigurative communism that held the workers' councils as their model and precedent. Being organized in assemblies, the workers' councils announced and anticipated the projected radical democracy, thereby prefiguring it. The goal was not only to pursue a free and egalitarian society but also to turn the internal structures of the movement into the genesis of a socialist future. The process itself had to anticipate the new world that was sought after. Thus, the means prefigured the end.

In no other place as in an assembly of a new movement could the tension between process and outcome be observed with more clarity. The goal of assemblies is not only to make a decision that embodies the plurality of perspectives but also to participate in a communitarian experience. To take the floor is not only intended to collaborate in making better decisions but also to allow self-expression and participation. Everything that has already been said should be said again by those who have not yet spoken. As Cornelius Castoriadis observed (1991), none of the new democrats advocating unlimited freedom of speech could sustain a redundant or empty speech without provoking a lusty booing from the crowd in classical Athens.

Overvaluing process to the detriment of the outcome is not a characteristic of the movements alone. Mainstream press coverage (and even the alternative press, which generally only reverses the stance of the dominant discourse) also focuses mostly on the process. The focus is directed toward the methods of the struggle, namely, the "violence" 
of vandalism and the creativity of the countercultural intervention. Little is said about the political demand that is at the root of the mobilization.

\section{THE TENSION BETWEEN PROCESSES AND OUTCOMES}

The tension between process and outcome may have its symbolic milestone in the one hundred thousand people march on the Pentagon, in Washington, DC on October 1967, when new and old movements' means of actions explicitly diverged. On one side, there was the traditional demonstration with speeches against the Vietnam War, organized by the National Mobilization Committee to End the War in Vietnam; on the other, the attempt to levitate the Pentagon with thousands chanting the "Om" mantra organized by Jerry Rubin, Abbie Hoffman and Allen Ginsberg. The debate about the attempt to levitate the Pentagon opposed, on one side, those who thought it was an unaccountable frivolity that would waste years of awareness campaign against the war and, on the other side, those who praised the mobilizing capacity of countercultural performance and the very procedural dimension of pure enjoyment and fun.

The movement against economic liberalization ("antiglobalization") perceived itself as unifying the social movements that had split in the 1970s. In that decade, the struggles of blacks, women, and students had fragmented and emancipated themselves from the unifying force of the labor movement. Neoliberalism simultaneously affected women, who were faced with poor working conditions in sweatshops; workers, who lost rights so that nation states could attract investment; and the environment, which lost instruments of legal protection to facilitate the expansion of economic enterprises. This broad spectrum of effects allowed groups to forge unity on the fight against neoliberalism. However, the practical instruments to achieve this goal were unclear because the process of economic liberalization was transnational; and thus, antineoliberal national initiatives were undermined by the shift of the financial capital to other markets. The absence of a clear strategy has contributed to the great emphasis placed on the processes.

The movement against economic liberalization discussed its processes a lot and was explicitly supported by the ideology of the prefigurative politics. The movement's debates on its internal democracy and struggle strategies was more important than the criticism against the adverse effects of market deregulation. "The decision was innocuous, but process was perfect," used to mock an influential activist from the Direct Action Network, after particularly insipid assemblies. When movements gathered in Seattle for a "non-violent" shut down of the Millennium Round of the World Trade Organization and a dissident group questioned the strategy of nonviolence, everything began to revolve around the Black Bloc. "Is the violence of the Black Bloc part of the world we want?", "Should the violence perpetrated by the resistance be judged in the 
same way as the violence of oppression?", "After all, is the destruction of property really violence?" Months later, because of this debate, the doctrine of diversity of tactics emerged, in which all forms of struggle were embraced in the Zapatista spirit of a world where many worlds fit. The WTO meeting was a fiasco, more due to disagreements between central and peripheral countries than to activities of the Direct Action Network and the Black Bloc. Despite this fact, the city walls were spray-painted with the message, "We are winning!"

In 2011, Adbusters magazine released the famous poster in which a ballerina danced over the bull that symbolizes the New York's Stock Exchange calling activists to occupy Wall Street. At the top of the poster, one could read the provocative question: "What is our one demand?" The goal was to challenge the future occupiers to mimic the Egyptian mobilization at Tahir's square which had a very specific one demand: the overthrown of Mubarak. Could the strategic objectivity of the Egyptians inspire the new movement's activists? The initial discussions about what would be Occupy Wall Street's one demand revolved around the Tobin tax or the creation of a presidential commission charged with ending the influence of money over the political system. None of the suggestions seemed to please the dissatisfactions enough. In its fifth communique the movement presented its one demand: "Ending capital punishment is our one demand (...) Ending wealth inequality is our one demand. (...) Ending police intimidation is our one demand. (...) Ending war is our one demand" Occupiers dreams couldn't fit in one demand. The movement decided it didn't want its 20 cents.

\section{PRINCIPALLISM AND OUTCOME-ORIENTED POLITICS}

New movements are extremely focused on processes. One reason is that adopting an outcome-oriented approach requires facing our discomfort with politics - a discomfort consolidated by a secular exclusion from public life.

Machiavelli stunned his time when he unveiled and defended the Medici family's use of "raison d'état" to pursue the patriotic task of uniting the entire territory of the Italian peninsula under a single rule. The experience he acquired in diplomatic life indicated two additional lessons: the recognition of a legality that is specific to the affairs of State and the understanding that common people were unable to understand it. Consequently, in politics, Machiavelli's prince must be exempted from the normative restrictions of private life while simultaneously pretending to live by them.

In the famous Munich conference to the students, Max Weber (2009) emphasizes Machiavelli's lesson to those young people who had just ascended to political responsibility through the German revolution. The illuminating contrast between the 
principallism of private morality and the outcome-oriented logic of politics was intended to prepare these new actors for the difficult dilemmas they were about to face.

During the cycle of struggles of the 1970's, the internal democracy of the new movements received a boost, but their inability to conduct politics also became clear. The reason was not only the hard dilemma of dirty hands, which has always been cause for hesitation even among statesmen and stateswomen. Trivial tasks that might compromise the radicalism of principles became systematically avoided. Speaking to the mass media, receiving donations, or negotiating with public authorities appeared not as tactical options to be judged regarding the practical outcomes of the struggle but as a commitment to the anti-capitalist ideals that were incompatible with corporate press, the market, and the State. Radicalism was no longer defined with respect to the ability of achieving a profound social transformation but to the integrity of idealism. Between the immobility of respecting principles and the risk of political action, immobility prevailed. Radicalism became apathetic.

Not only have the new movements been unable or unwilling to determine clear strategic goals, they have been unable to undertake practical tasks that could compromise political principles. The rising of new movements showed a transformation potential that remained mostly inactualized by the principallism of those who have been traditionally excluded from politics. Even simple tasks such as talking to the press, receiving donations or negotiating with institutions were considered compromises to the movements' principles that opposed corporate press, the state and capital. Attempts to openly face this principallism usually resulted in harsh accusations of pragmatism. Curiously though, the secret history of most of these struggles is that of pragmatic "leaders" whom, without the movement's acknowledge, carried out the necessary tasks that no one else wanted to undertake. The outcome is paradoxical: movements that, on one hand, value their democratic process above everything and, on other hand, risk this very democracy because of their inability to handle result-oriented tactics and strategies.

If the developing of struggles in capitalism deepens democracy (i.e., if the struggle somehow prepares the upcoming of a free and egalitarian society), then that process must incorporate a growing ability to engage in politics. The appraisal for creativity and democracy in the movements must be combined with the mature understanding that politics is measured by outcomes. The immanent logic of political action unveiled by Machiavelli must be dissolved in a democratic process in which domination and fraud gives place to a transparent, emancipatory strategy. We need a diffuse Machiavellianism—a moral philosophy for the multitude in antagonism. 


\section{COMBINING CARING FOR PROCESSES AND AIMING AT OUTCOMES}

The June 2013 protests in Brazil leave two opposite legacies: on one hand, the explosion of demonstrations with widespread agendas and no focus on outcomes; on the other, the struggle against the rise in bus and metro fares driven by the Free Fare Movement (Movimento Passe Livre), with a deep sense of tactics and strategy.

In the decisive moment of the campaign against the rise in fares, the movement was assailed by the widening of the agenda. When the increase in fare was reversed, the struggle became orphan, and a widespread agenda took over the process. A procedural activism not focused on results prevailed. This process was even more extreme than similar phenomena in other countries. The movement faced not only difficulties in finding a workable common goal, as was seen in the Occupy Wall Street movement or the Spanish 15M, but also in defining a common ideological horizon, even a vague one. In the absence of political orientation, the movement was consumed by procedural issues, such as struggle tactics. It is no coincidence that the debates of the late 1990s around the Black Bloc reemerged with full force. The debate was now about the limits between a respectable civil mobilization and criminal vandalism. Without clear objectives, processes were discussed based on principles and with no relation to outcomes. In that respect, June 2013 was an explosion of widespread outrage - an enigma to be deciphered by mainstream media.

The strategy of the Free Fare Movement was developed from learning from earlier struggles. In 2003, students in the city of Salvador blocked roads in a protest against the rise in bus fares. The mobilization was spontaneous and horizontal, but lacked people or groups of reference legitimated by the movement to negotiate with the government. In the absence of spokespersons, the national student union UNE played the role and subjected students demands of reducing bus fares to its own party agenda. The creation of the Free Fare Movement is a response to the understanding that the revolt of youth against bus fares needed a political expression that was both horizontal and exclusively against fare increases - i.e. an organization that would comply both with the movement's processes and outcomes.

The movement developed and unfolded the inner rationale emanating from youth and student struggles against fare prices. The struggle evolved from demanding half fare for students in the 1980s, to demanding free fare to students in the 1990s, and then to fighting bus fare increases in the 2000s. This process reveals the logic of the struggle for an expansion of rights that, if successful, would lead to free fare for all and the decommodification of public transportation. This understanding was not imposed by an external Leninist program but was extracted from the autonomous struggle of the students. 
The lessons learned in almost ten years of struggle have enabled the movement to value process while remaining outcome-oriented. On one hand, the movement was successful in preserving and cultivating a horizontal and countercultural logic - a logic that was derived from both the students' struggle against the rise in fares and the movement against economic liberalization from where many of its first activists come. On the other hand, the movement established, in a tactical way, an achievable objective goal: the repeal of fare rises. However, this short-term goal is intrinsically linked to a more ambitious target: transforming a commodified service into an universal social right.

The repeal of the fare rise created a precedent for reducing the price of the fare. By winning the demand of reducing the rise in fares, the whole logic of annual fare increases is reversed and the ultimate goal of the movement which is free transportation for all goes to the center of public debate. The most important legacy of the June protests was the double victory of reducing fare prices and bringing to public debate the issue of publicly funded free transportation by means of autonomous action with a clear strategy. This legacy is not only a new paradigm for social struggles in Brazil but a model for movements everywhere that combines the horizontal and countercultural politics of the new movements with a mature sense of strategy.

\section{REFERENCES}

BOGGS, Carl. Marxism, Prefigurative Communism, and the Problem of Workers' Control. Radical America, v. 4, n. 6, p. 99 - 122, 1977.

CASTORIADIS, Cornelius. Philosophy, Politics, Autonomy. Oxford: Oxford University Press, 1991.

TRONTI, Mario. Operai e capitale. Roma: DeriveApprodi, 2006 [1966].

WEBER, Max. Politics as Vocation. In: GERTH , H. H.; WRIGHT MILLS, C. (ed.) From Max Weber: Essays in Sociology. New York: Routledge, 2009. 